\title{
UJI PEMOMPAAN AIR TANAH METODE STEP DRAW DOWN UNTUK MENGETAHUI DEBIT OPTIMUM KEMAMPUAN SUMUR BOR
}

\author{
Jarwanto $^{1 *}$, Rudy Hendrawan Noor ${ }^{1}$ \\ ${ }^{1}$ Dosen Jurusan Teknik Pertambangan - Akademi Teknik Pembangunan Nasional Banjarbaru - \\ Kalimantan Selatan \\ 1*jarwanto_bjb@yahoo.com
}

\begin{abstract}
ABSTRAK
Uji pemompaan dalam kaitannya dengan kemampuan sumur terhadap akuifer dalam penyediaan air dalam tubuh formasi batuan. Pengukuran ini didapat dari respon terhadap kenaikan maupun penurunan air saat dilakukan pemompaan dengan melalui 3 tahap (step) perlakuan dengan posisi Q1, Q2 dan Q3. Posisi Q3 maksimum pompa yang digunakan, Q2 didapat dari setengah dari nilai Q3, Q1 setengah dari Q2 (paling kecil). Pemompaan selama 960 menit tanpa henti dari 3 step akan menurunkan muka air tanah dengan panjang 47,75 meter. Recovery kembali ke muka air tanah semula selama 390 menit. Dengan pendekatan tabel didapatkan nilai optimum dalam pemompaan sebesar 1,7 liter/detik dengan posisi muka air tanah stabil dan seimbang yang dihitung dari ketersediaan air dalam formasi batuan/tanah dengan pemompaan yang dilakukan terus menerus tanpa henti. Sumur bor dapat difungsikan untuk kegiatan usaha maupun rumah tangga bahkan untuk pengairan persawahan/pertanian lainnya.
\end{abstract}

Kata Kunci : Pemompaan, Air tanah, Debit optimum, sumur bor

\section{PENDAJULUAN}

Prinsip uji pemompaan melibatkan aplikasi tekanan buatan pada akifer dengan mengekstraksi air tanah dari sumur pompa dan mengukur respon dari tekanan buatan dengan memperhatikan tingkat penurunan muka air dalam fungsi waktu dan kedalaman. Pengukuran di korelasikan dengan persamaan aliran sumur dan menghitung parameter hidrolik dari akifer.

Pada prinsipnya uji dilakukan untuk mengetahui :

- Jumlah air tanah yang dapat diekstraksi dari sumur berdasar parameter waktu.

- Perbedaan ketinggian kolom atgau kedalaman air.

- Mengetahui ketinggian yang ideal dari pompa pada sumur.

- Memberikan informasi kuantitas air yang berhubungan dengan dengan waktu.

Data pendukung yang diperlukan :

- Debit dari pompa

- Kedalaman sumur

- Ketinggian muka air awal mula

- Diameter sumur (inch)

- Ketinggian dinding sumur di atas permukaan tanah
- Waktu Uji Pemompaan

- Waktu kembali (Recovery)

Peralatan sederhana uji pemompaan yang disiapkan antara lain :

- pompa air dengan spesifikasi output aktual (dengan cara menadah air yang keluar dari pompa dengan menghitung waktu (detik), hasilnya berupa liter / detik)

- penyiapan berupa alat sederhana yang meluluskan air untuk keluar dan sebagian mengembalikan air ke sumur.

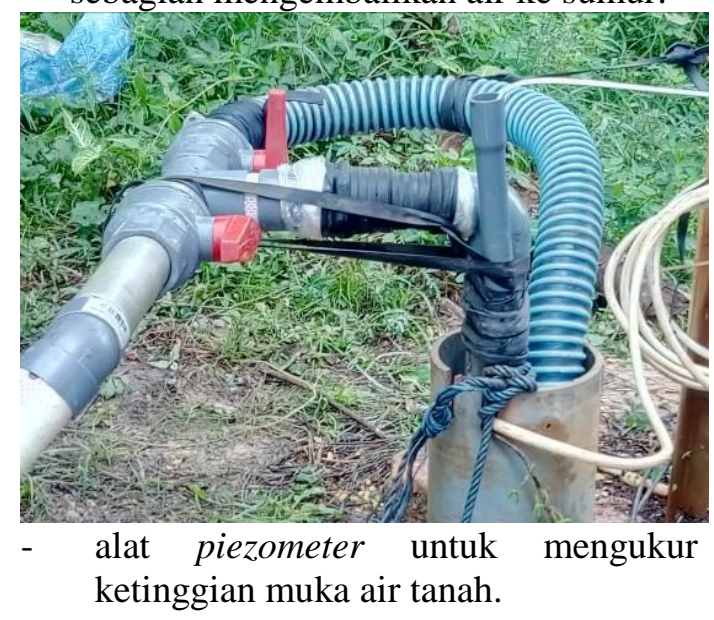




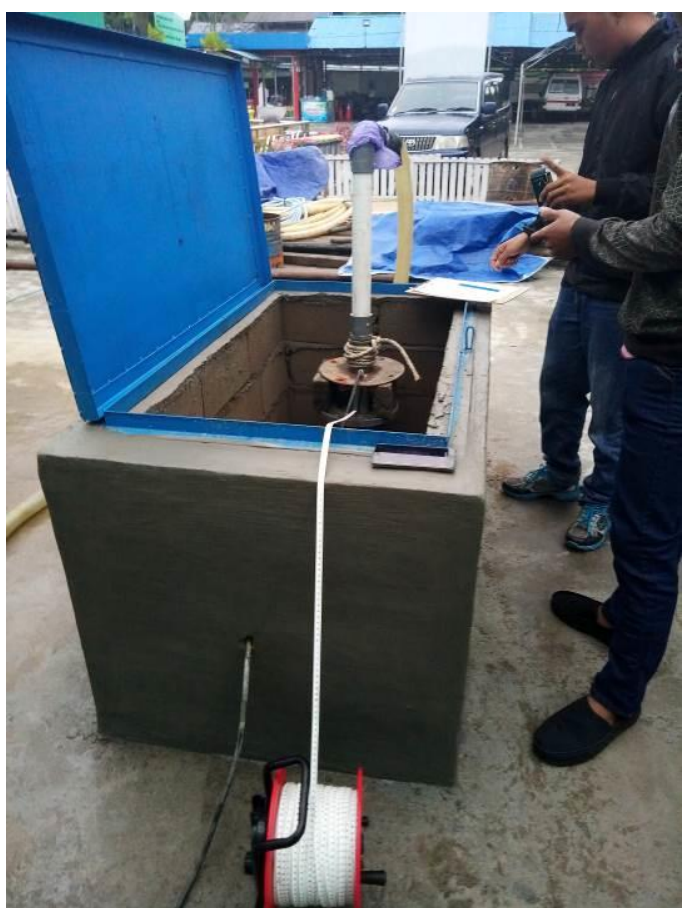

\section{Mengetahui Debit Aktual Pompa}

Pompa dapat diketahui debitnya dengan cara menyiapkan wadah tumpahan air yang dipompa. Dimulai dari 0 detik saat wadah kosong dan diakhiri waktunya saat wadah telah penuh. Contoh : Pada 0 detik air yang keluar dari pompa dimasukkan ke wadah, misalnya ember dengan kapasitas 40 liter. Biarkan ember terisi air hingga penuh. Misal waktu dari 0 detik awalnya dan berakhir setelah penuh pada detik ke 20. Dengan demikian dapat diketahui, kapasitas pompa aktual sebesa 40 liter bagi 20 detik sehingga didapatkan debit : 40 lt $/ 20$ detik $=2$ liter/detik .

\section{Persiapan Pumping Test}

Pipa dengan diameter sebesar 2" dipersipakan untuk metode pumping test ini.

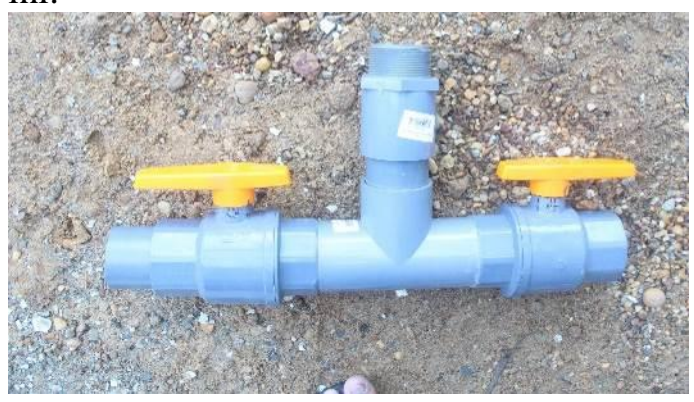

Alat dibuat menjadi cabang 2 senagai output, keduanya diberi tuas untuk mengatur keluarnya air dari lubang input yang ada drat-nya.
Pada alat yang sudah disiapkan, selanjutnya menentukan koefisien Q3 (debit terbesar), Q2 (debit menengah) dan Q1 (debit terkecil). Nilai Q3 merupakan nilai terbesar dari debit yang akan diukur. Caranya dengan memberikan output dari tuas alat pada posisi tertinggi, sedangkan pada tuas alat satunya dibuka pada posisi terkecil. Hal ini mengindikasikan bahwa tuas pada output lebih besar dari tuas yang alirannya dikembalikan lagi ke sumur. Sehingga nilai Q3 sebagai debit maksimum dapat menggunakan angka debit yang telah diketahui, misalnya debit 2 lt/det seperti contoh diatas.

Pada Q2 , tuas output disetel menengah dan yang dikembalikan ke sumur juga disetel menengah, sehingga antara yang keluar dan yang dimasukkan ke sumur lagi menjadi seimbang. Q2 ditentukan sebagai setengah dari Q3, sehingga didapatkan $1 / 2 \times \mathrm{Q} 3=1 / 2 \times 2=1 \mathrm{lt} / \mathrm{det}$.

Berbeda dengan Q3 dan Q2, Qi didapat dengan memperkecil tuas output tapi memperbesai tuas yang kembali ke sumur. Sehingga air yang keluar lebih sedikit dan yang kembali ke sumur lebih banyak. Q1 sebagai yang terkecil adalah setengah dari Q2, sehingga didapatkan : 1/2 x Q2 = 1/2 x $1=1 / 2$ lt $/$ det. Masing-masing Q1, Q2 dan Q3 pada masing-masing tuas diberi tanda pada alat.

\section{Kerja Pumping Test}

Dimulai pada metode Step draw down test, tuas pada posisi Q1. Output kecil, tetapi air yang kembali ke sumur lebih besar. Pencatatan sesuai tabel yang dicatat mulai detik awal hingga selesai untuk Q1. Pada 10 menit awal, pencatatan posisi permukaan air dimulai dari menit pertama hingga menit ke sepuluh dengan interval tiap 1 menit. Selanjutnya tiap 2 menit dimulai dari menit ke 12, 14 hingga menit ke 20. Selanjutnya tiap lima menit dimulai dari menit ke 25, 30 hingga menit ke 60.

Pencatatan selanjutnya dari menit ke 60 tiap 10 menit hingga menit ke 120 . Sisanya tiap 60 menit hingga akhir menit ke 360. Bila pada menit-menit tertentu posisi permukaan air tanah stabil selama 4 kali bertuurut-turut (contoh menit ke 40, 5055 dan 60 pada posisi permukaan air tanah sama), maka Q1 dapat diakhiri dan 
selanjutnya beralih ke Q2 tanpa mematikan pompa hanya mengubah posisi tuas pada posisi Q2 (out put menengah dan air yang kembali ke sumur juga posisi menengah) Step kerja pada posisi Q2 metodenya hampir sama dengan saat posisi di Q1. Pada metode Step draw down test tuas pada posisi Q2 dengan output menengah, dan air yang kembali ke sumur juga posisi menengah. Pencatatan sesuai tabel yang dicatat mulai detik awal hingga selesai untuk Q2. Pada 10 menit awal, pencatatan posisi permukaan air dimulai dari menit pertama hingga menit ke sepuluh dengan interval tiap 1 menit. Selanjutnya tiap 2 menit dimulai dari menit ke 12, 14 hingga menit ke 20. Selanjutnya tiap lima menit dimulai dari menit ke 25, 30 hingga menit ke 60.

Pencatatan selanjutnya dari menit ke 60 tiap 10 menit hingga menit ke 120 . Sisanya tiap 60 menit hingga akhir menit ke 360. Bila pada menit-menit tertentu posisi permukaan air tanah stabil selama 4 kali bertuurut-turut (contoh menit ke 40, 5055 dan 60 pada posisi permukaan air tanah sama), maka Q2 dapat diakhiri dan selanjutnya beralih ke Q3 tanpa mematikan pompa hanya mengubah posisi tuas pada posisi Q3 (out put terbesar dan air yang kembali ke sumur juga posisi terkecil). Untuk posisi Q3 dengan output terbesar dan air yang kembali pada posisi terkecil, pencatatan dilakukan sama dengan saat Q1 dan Q2. Step kerja pada posisi Q3 metodenya hampir sama dengan saat posisi di Q2. Pada metode Step draw down test tuas pada posisi Q3 dengan output terbesar, dan air yang kembali ke sumur posisi terkecil. Pencatatan sesuai tabel yang dicatat mulai detik awal hingga selesai untuk Q3.

Pada 10 menit awal, pencatatan posisi permukaan air dimulai dari menit pertama hingga menit ke sepuluh dengan interval tiap 1 menit. Selanjutnya tiap 2 menit dimulai dari menit ke 12, 14 hingga menit ke 20. Selanjutnya tiap lima menit dimulai dari menit ke 25, 30 hingga menit ke 60. Pencatatan selanjutnya dari menit ke 60 tiap 10 menit hingga menit ke 120. Sisanya tiap 60 menit hingga akhir menit ke 360.
Bila pada menit-menit tertentu posisi permukaan air tanah stabil selama 4 kali bertuurut-turut (contoh menit ke 40, 50 55 dan 60 pada posisi permukaan air tanah sama), maka Q3 dapat diakhiri . Bila hingga akhir Q3 juga belum stabil, maka angka atau waktu seperti di tabel dapat ditambah dengan menambahkan interval tiap 1 jam.

Bila telah stabil (4 kali berturutturut data permukaan air tanah sama), maka pompa dimatikan dan dilanjutkan dengan recovery test. Pada recovery test ini, posisi pompa mati, artinya air tanah kembali mengisi sumur yang sebelumnya disedot daat test pada Q1, Q2 dan Q3. Pencatatan dimulai dari menit pertama hingga menit ke 10 untuk interval 1 menit. Selanjutnya pencatatan tiap interval 5 menit setelah menit ke - 10. Pada menit ke 30 pencatatan posisi permukaan air tanah di catat pada interval 15 menit dari menit ke 45, 60, 75 hingga 90. Dari interval menit ke 30 dicatat mulai menit 120, 150 hingga 240. Interval diubah dari interval 30 menit, interval 40 menit. Pada interval 50 menit dimulai pada posisi menit ke 390 hingga menit ke 840.

Bila diperlukan dan bila permukaan air tanah belum kembali ke posisi semula saat dimulainya Q1, maka pencatatan dapat dilanjut tiap interval 50 menit setelah menit ke 840. Bila telah kembali ke posisi semula saat Q1, maka pada step draw down test ini telah berakhir dan dimulai kagi untuk metode continous rate test.

Pada prinsipnya, metode ini memompa air tanah menerus tanpa perubahan posisi seperti pada metode sebelumnya. Posisi tuas pada Q3 (output terbesar dan air yang kembali ke sumur pada posisi terkecil). Seperti sebelumnya, Pencatatan tiap interval 1 menit dimulai pada menit pertama hingga menit ke 10 . Selanjutnya tiap 5 menit dimulai pada menit ke 15 hingga menit ke 30 , interval 10 menit dimulai pada menit ke 30 hingga menit ke 100. Selanjutnya interval 20 menit dimulai dari menit ke 120 hingga menit ke 200. Pada menit selanjutnya interval berubah menjadi 50 menit hingga menit ke 500. Selanjutnya interval 80 menit pada menit 580 dan 660, terakhir pada menit ke 750 dan 840 . Bila masih belum stabil dapat 
dilanjutkan dengan interval 90 menit setelah menit 840 .

Bila dinyatakan sudah stabil maka pompa dimatikan dan dilanjut pencatatan muka air tanah pada posisi recovery sehingga didapatkan data dengan pencatatan tiap 1 menit mulai menit pertama hingga menit ke 10 . Selanjutnya interval 5 menit hingga menit ke 30 . Interval diubah lagi ke interval 15 menit mulai dari menit ke 30 hingga menit ke 90 . Interval 30 menit dimulai dari menit selanjutnya hingga menit ke 330. Selanjutnya pencatatan posisi permukaan air tanah pada menit ke 360, 380, 480, 600, 720 dan 840 .

\section{DATA LAPANGAN}

Muka air tnaah statis berada pada posisi 12,86 meter bawah permukaan tanah yang diukur dari kepala sumur dengan diameter sebesar 6". Pipa hanatar sebesar 2" dengan pompa yang digunakan merk Grundfos type submersible dengan kekukatan 2 HP. Letak pompa berada pada 80 meter bawah permukaan tanah, sedangkan kedalaman sumur itu sendiri berada pada kedalaman 100 meter bawah permukaan tanah. Debit Flowing dari sumur yang diuji adalah 3,1 liter/detik,

Tabel Q1 = 0,75 liter/detik

\begin{tabular}{|c|c|c|c|}
\hline \multicolumn{2}{|c|}{$\begin{array}{ll}\mathrm{Q} 1= & \begin{array}{l}0.75 \\
(\mathrm{lt} / \mathrm{dt})\end{array} \\
\end{array}$} & \multirow{2}{*}{\begin{tabular}{|l} 
Waktu \\
(menit)
\end{tabular}} & \multirow{2}{*}{$\begin{array}{l}\text { Penurunan } \\
\text { Muka Air } \\
\text { (m) }\end{array}$} \\
\hline \multirow{2}{*}{$\begin{array}{l}\text { Waktu } \\
\text { (menit) }\end{array}$} & \multirow{2}{*}{$\begin{array}{c}\text { Penurunan } \\
\text { Muka Air } \\
(\mathrm{m})\end{array}$} & & \\
\hline & & 12 & 16.01 \\
\hline 0 & 12.86 & 14 & 16.28 \\
\hline 1 & 13.17 & 16 & 16.49 \\
\hline 2 & 13.53 & 18 & 16.71 \\
\hline 3 & 13.98 & 20 & 16.92 \\
\hline 4 & 14.15 & 25 & 17.13 \\
\hline 5 & 14.34 & 30 & 17.34 \\
\hline 6 & 14.53 & 35 & 17.54 \\
\hline 7 & 14.73 & 40 & 17.74 \\
\hline 8 & 15.00 & 45 & 17.94 \\
\hline 9 & 15.39 & & \\
\hline 10 & 15.69 & & \\
\hline
\end{tabular}

Pada posisi Q1=0,75 liter/detik air yang keluar dari pompa didapatkan penurunan $0,31 \mathrm{~cm}$ yang didapat dari poisisi muka air tanah semula $12,86 \mathrm{mmbt}$ saat 1 menit dipompa, posisi muka air tanah menjadi 13,17 mmbt. Demikian juga untuk data selanjutnya sepereti berikut:

\begin{tabular}{|c|c|}
\hline Waktu & $\begin{array}{c}\text { Penurunan } \\
\text { Muka Air } \\
\text { (menit) }\end{array}$ \\
\cline { 2 - 2 } 50 & 18.14 \\
55 & 18.32 \\
60 & 18.48 \\
70 & 18.62 \\
80 & 18.74 \\
\hline 90 & 18.84 \\
100 & 18.92 \\
110 & 18.98 \\
120 & 19.02 \\
180 & 19.04 \\
\hline 240 & 19.04 \\
300 & 19.04 \\
360 & 19.04 \\
\hline \hline Waktu & Penurunan \\
Muka Air \\
(menit)
\end{tabular}

\begin{tabular}{|c|c|}
\hline $\mathrm{Q} 2=$ & $\begin{array}{r}1.5 \\
(\mathrm{lt} / \mathrm{dt})\end{array}$ \\
\hline $\begin{array}{l}\text { Waktu } \\
\text { (menit) }\end{array}$ & $\begin{array}{c}\text { Penurunan } \\
\text { Muka Air } \\
\text { (m) }\end{array}$ \\
\hline 360 & 19.04 \\
\hline 361 & 21.04 \\
\hline 362 & 21.84 \\
\hline 363 & 22.55 \\
\hline 364 & 23.17 \\
\hline 365 & 23.75 \\
\hline 366 & 24.32 \\
\hline 367 & 24.88 \\
\hline 368 & 25.47 \\
\hline 369 & 25.92 \\
\hline 370 & 26.42 \\
\hline $\begin{array}{l}\text { Waktu } \\
\text { (menit) }\end{array}$ & $\begin{array}{l}\text { Penurunan } \\
\text { Muka Air } \\
\text { (m) }\end{array}$ \\
\hline 410 & 32.33 \\
\hline 415 & 32.85 \\
\hline 420 & 33.36 \\
\hline 430 & 33.94 \\
\hline 440 & 34.54 \\
\hline 450 & 35.07 \\
\hline 460 & 35.65 \\
\hline 470 & 36.21 \\
\hline 480 & 36.77 \\
\hline 540 & 37.49 \\
\hline 600 & 38.17 \\
\hline 660 & 38.77 \\
\hline 720 & 39.38 \\
\hline $\begin{array}{l}\text { Waktu } \\
\text { (menit) }\end{array}$ & $\begin{array}{l}\text { Penurunan } \\
\text { Muka Air } \\
\text { (m) }\end{array}$ \\
\hline 732 & 52.75 \\
\hline 734 & 53.89 \\
\hline 736 & 54.93 \\
\hline 738 & 55.65 \\
\hline 740 & 56.15 \\
\hline 745 & 56.55 \\
\hline 750 & 57.06 \\
\hline 755 & 57.88 \\
\hline 760 & 58.10 \\
\hline 765 & 58.17 \\
\hline
\end{tabular}

\begin{tabular}{|c|c|c|c|c|}
\hline $\begin{array}{c}\text { Waktu } \\
\text { (menit })\end{array}$ & $\begin{array}{c}\text { Penurunan } \\
\text { Muka Air } \\
(\mathrm{m})\end{array}$ & & $\begin{array}{c}\text { Waktu } \\
\text { (menit) }\end{array}$ & $\begin{array}{c}\text { Penurunan } \\
\text { Muka Air } \\
(\mathrm{m})\end{array}$ \\
\cline { 1 - 1 } 720 & 39.38 & 732 & 52.75 \\
721 & 41.85 & 734 & 53.89 \\
722 & 43.39 & 736 & 54.93 \\
723 & 44.86 & & 738 & 55.65 \\
724 & 45.77 & & 740 & 56.15 \\
725 & 46.40 & 745 & 56.55 \\
\hline 726 & 47.50 & 750 & 57.06 \\
727 & 48.84 & 755 & 57.88 \\
728 & 49.19 & 760 & 58.10 \\
729 & 50.43 & 765 & 58.17 \\
730 & 51.65 & & \\
\hline
\end{tabular}




\begin{tabular}{|c|c|}
\hline $\begin{array}{c}\text { Waktu } \\
\text { (menit) }\end{array}$ & $\begin{array}{c}\text { Penurunan } \\
\text { Muka Air } \\
(\mathrm{m})\end{array}$ \\
& 59.34 \\
775 & 59.54 \\
780 & 59.75 \\
790 & 59.98 \\
800 & 60.22 \\
\hline 810 & 60.37 \\
820 & 60.46 \\
830 & 60.52 \\
840 & 60.56 \\
900 & 60.59 \\
\hline 960 & 60.61 \\
1020 & 60.61 \\
1080 & 60.61 \\
\hline RECOVERY TEST \\
\hline Waktu & Tinggi \\
(menit) & Muka Air \\
(m)
\end{tabular}

Pada posisi menit ke 960, posisi muka air tanah pada $60,61 \mathrm{mmbt}$, stabil hingga menit ke 1080. Setelah mesin pompa dimatikan akan recovery seperti tabel :

\begin{tabular}{|c|c|}
\hline \multicolumn{2}{|c|}{ RECOVERY TEST } \\
\hline Waktu & $\begin{array}{c}\text { Tinggi } \\
\text { Muka Air } \\
(\mathrm{m})\end{array}$ \\
\cline { 2 - 2 } (menit) & 19.42 \\
15 & 18.54 \\
20 & 17.69 \\
25 & 16.35 \\
30 & 15.97 \\
45 & 15.03 \\
\hline 60 & 14.35 \\
75 & 13.93 \\
90 & 13.56 \\
120 & 13.41 \\
150 &
\end{tabular}

\begin{tabular}{|c|c|}
\hline \multicolumn{2}{|c|}{ RECOVER TEST } \\
\hline Waktu & $\begin{array}{c}\text { Tinggi } \\
\text { Muka Air } \\
\text { (m) }\end{array}$ \\
\cline { 2 - 2 } (menit) & 13.25 \\
180 & 13.17 \\
210 & 13.06 \\
270 & 13.00 \\
300 & 12.95 \\
\hline 340 & 12.91 \\
390 & 12.86 \\
\hline
\end{tabular}

Pada menit ke 390 saat dimaulainya recovery, muka air tanah sudah stabil pada 12,86 mmbt. dengan selisih dari penurunan yang dijadikan acuan pada angka muka statis 12,86 mmbt maka didapatkan tampilan grafik sebagai berikut :

Grafik Penurunan muka air tanah dengan recovery.

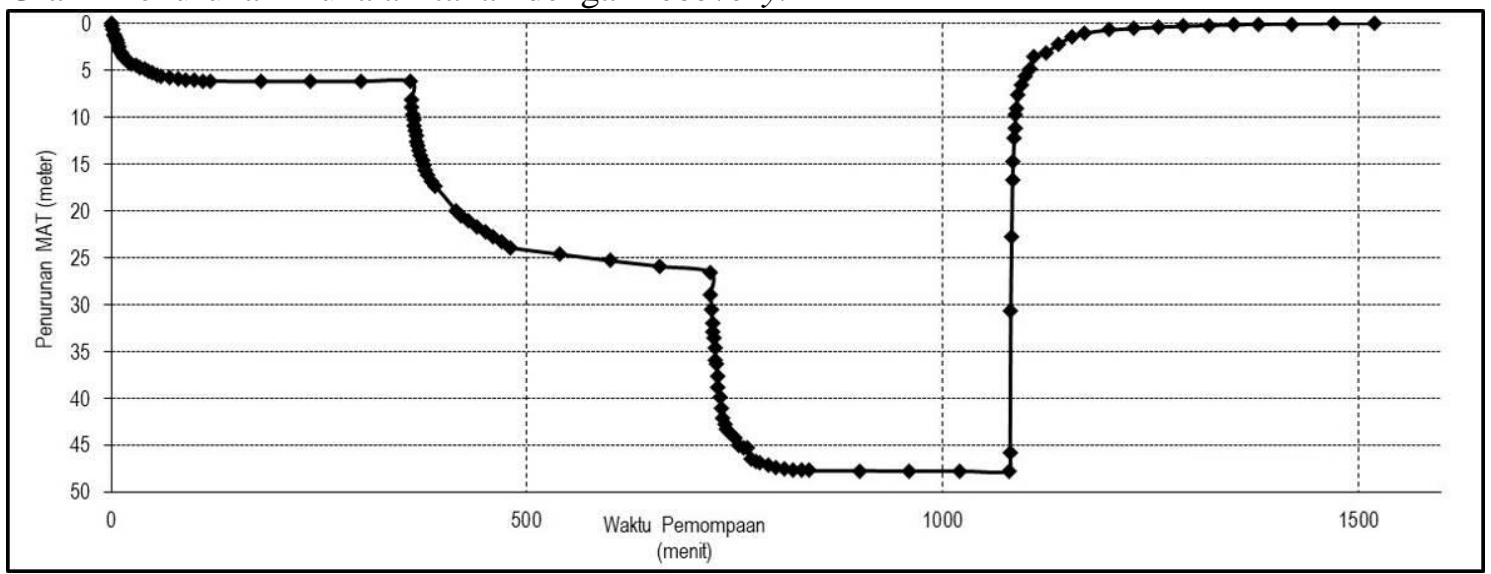

Dengan demikian, bila dimasukkan dalam tabel debit air yang dipompa didapatkan angka 1,7 liter/detik (atau 0,0017 m3/detik) 


\begin{tabular}{|c|c|c|c|c|c|c|c|}
\hline \multicolumn{8}{|c|}{$Q_{\text {maks. }}, Q_{\text {opt. }}, S W$ opt. } \\
\hline $\begin{array}{c}\text { Debit Q } \\
\mathrm{m}^{3} / \mathrm{dt}\end{array}$ & $\begin{array}{c}\text { Aquifer Loss } \\
\text { BQ }\end{array}$ & $\begin{array}{c}\text { Well Loss } \\
\mathrm{CQ}^{2}\end{array}$ & $\begin{array}{l}\text { Penurunan } \\
\text { Total, (Swt) }\end{array}$ & $\begin{array}{c}\mathrm{f}\left(\mathrm{Q}_{\max }\right) \\
\text { Linier }\end{array}$ & $\begin{array}{l}Q_{\text {opt }} \\
\mathrm{m}^{3} / \mathrm{dt}\end{array}$ & $\begin{array}{l}\mathrm{Sw}_{\mathrm{opt}} \\
\text { (meter) }\end{array}$ & $\begin{array}{c}\text { Efisiensi } \\
(\%)\end{array}$ \\
\hline & 0 & 0 & 0 & 58.38 & & & \\
\hline 0.00075 & 8.39 & 1.5505 & 9.94 & 43.78 & & & \\
\hline 0.00150 & 16.78 & 6.2021 & 22.99 & 21.89 & & & \\
\hline 0.00300 & 33.57 & 24.8086 & 58.38 & 0.00 & & & \\
\hline$Q_{\max }$ & & & Sw max & & 0.0017 & 26.12 & 71.00 \\
\hline
\end{tabular}

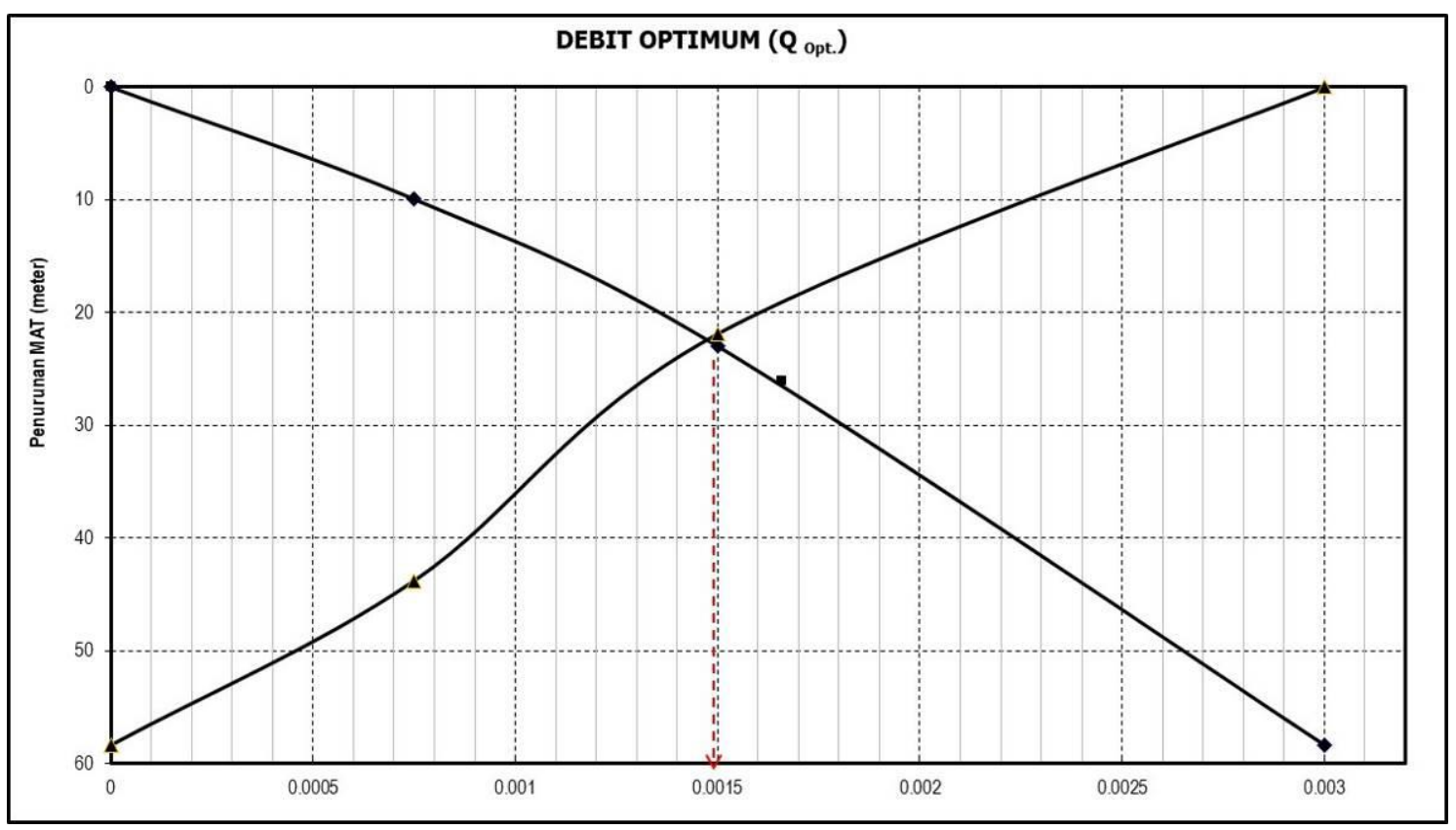

Dengan menggabungkan nilai penurunan muka air tanah dengan debit minimum maupun maksimum didapatkan angka optimum sebesar $0,0017 \mathrm{~m} 3 /$ detik. Debit ini diperuntukkan bagi sumur dengan kapasitas yang dapat menyediakan air dari akuifer dalam formasi batuan. Bila debit optimum telah diketahui maka bila air dipompa melebihi dari kapasitas optimum maka kemampuan air tanah yang dipompa akan mengalami stag karena pompa yang digunakan melebihi kapasitas air yang tersedia dalam tanah.

Penggunaan sistem ini diperuntukkan bagi kegiatan usaha maupun rumah tangga bahkan untuk pengairan persawahan/pertanian lainnya sehingga air cukup tersedia didalam formasi batuan.

\section{KESIMPULAN}

Letak muka air tanah semula sebesar 12,86 mmbt (meter muka bawah tanah) dilakukan pemompaan dengan 3 step yang dipompa dengan daya Q1 0,75 lt/detik, Q2 1,5 1t/detik dan Q3 3 lt/detik menjadi permukaan air tanah yang sudah stabil pada posisi 60,61 mmbt selama 960 menit tanpa henti. Terdapat selisih 47,75 meter dengan recovery selama 390 menit. Pemompaan saat maksimum 3 liter/detik menghasilkan 1,7 liter/detik optimum dalam pemompaan yang dapat difungsikan dalam kegiatan usaha maupun rumah tangga bahkan untuk pengairan persawahan/pertanian lainnya sehingga air cukup tersedia didalam formasi batuan seimbang dengan jumlah pemakaian.

\section{DAFTAR PUSTAKA}

Freeze R.A. \& Cherry, 1979, Groundwater, Prentice Hall, Inc. United State of America.

Todd, DK., 1984, Groudwater Hydrology, 2nd ed, John Willey \& Sons, New York USA. 